\title{
BUDAYA ORGANISASI DALAM PELAYANAN WISATAWAN \\ MENGHADAPI ADAPTASI KEBIASAAN BARU (AKB) PADA PT. SARI ATER HOTEL \& RESORT
}

\author{
Iwan Henri Kusnadi ${ }^{1}$ \\ Fakultas Ilmu Administrasi Universitas Subang \\ iwanhenri01@gmail.com
}

\section{Ade Suparman ${ }^{2}$}

Fakultas Ilmu Administrasi Universitas Subang

suparmanade09@gmail.com

\section{Ine Mariene ${ }^{3}$}

FISIP Universitas Pasundan

ine.mariane@unpas.ac.id

\begin{abstract}
Abstrak
Perusahaan tanpa sumber daya manusia yang baik dalam strategi serta operasional tidak akan mampu mencapai tujuan perusahaan. Berhasil atau gagalnya tujuan perusahaan tidak terlepas dari bagaimana kinerja karyawanya. Organisasi dituntut mempertahankan karyawannya agar menghasilkan kinerja yang baik serta karyawan dapat mendedikasikan diri kepada organisasi di mana karyawan bekerja. Permasalahan kinerja karyawan masih menjadi permasalahan serius bagi banyak perusahaan baik dalam bidang manufaktur ataupun jasa. Salah satu perusahaan yang mengalami masalah kinerja yaitu PT. Sari Ater Hotel dan Resort Subang. Adapun upaya yang dilakukan oleh PT. Sari Ater Hotel dan Resort Subang untuk meningkatkan kinerja yaitu dengan cara meningkatkan kemampuan kerja dan melakukan coaching kepada karyawannya.
\end{abstract}

Kata Kunci : Kemampuan bekerja, Budaya Organisasi

\begin{abstract}
Companies without human resources that are good in strategy and operations will not be able to achieve company goals. Success or failure of company goals is inseparable from how their employees perform. The organization is required to retain its employees to produce good performance and employees so that they dedicate themselves to the organization in the workplace. Employee performance issues are still a serious problem for many companies, both in manufacturing and services. One of the companies that experiences performance problems is PT. Sari Ater Hotel and Resort Subang. The efforts
\end{abstract}




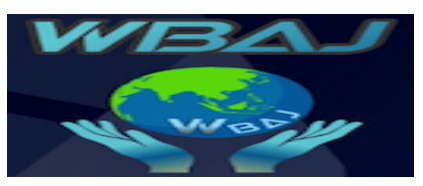

Volume 2 Issue 1, Juni 2020

https:/ / ejournal.unsub.ac.id/index.php/bisnis

have been made by PT. Sari Ater Hotel and Resort Subang to organization of culture; it is by increasing the workability and coaching to its employees.

Keywords: Workability, organization culture

\section{Pendahuluan}

Budaya organisasi kini sedang menjadi perbincangan dimana mana, baik dikalangan para pakar maupun dikalangan praktisi bisnis dan para eksekutif, karena organisasi tersebut banyak yang berhasil membuat suatu organisasi menjadi lebih stabil, lebih maju, lebih antisipatif terhadap perubahan lingkungan. Budaya organisasi dipahami sebagai apa yang dirasakan pekerja dan bagaimana persepsi ini menciptakan keyakinan, nilai-nilai, dan harapan. Ini berarti budaya organisasi adalah sesuatu yang dapat membedakan antara organisasi yang satu dengan organisasi perusahaan yang lainnya, karena budaya organisasi adalah identitas dari suatu organisasi perusahaan tersebut. Disamping itu budaya organisasi yang baik dapat membantu berlangsungnya kegiatan dalam suatu organisasi berjalan dengan baik, sebagai contoh apabila setiap karyawan dapat berdisiplin dalam segala hal terhadap pekerjaannya masing-masing maupun kelompok maka hal ini akan menjadi suatu budaya yang baik dalam suatu organisasi yang akan memunculkan komitmen dan tanggung jawab yang baik pula terhadap perusahaan. Budaya organisasi adalah suatu sistem nilai yang diperoleh dan dikembangkan oleh organisasi dan pola kebiasaan dan falsafah dasar pendirinya, yang terbentuk menjadi aturan yang digunakan sebagai pedoman dalam berfikir dan bertindak dalam mencapai tujuan organisasi.

Budaya yang tumbuh menjadi kuat mampu memacu organisasi kearah perkembangan yang lebih baik. Budaya organisasi dapat mempengaruhi profesionalisme kerja pegawai di PT. Sari Ater, karena menciptakan interaksi antar pegawai dan pola perilaku bagi pegawai di PT. Sari Ater untuk memberikan kemampuan terbaiknya dalam memanfaatkan kesempatan yang diberikan oleh organisasinya. Nilai-nilai yang dianut bersama dalam organisasi membuat pegawai merasa nyaman bekerja, memiliki komitmen dan kesetiaan serta membuat pegawai berusaha lebih keras, meningkatkan profesionalissme kerja pegawai, dan mempertahankan keunggulan kompetitif. Budaya organisasi merupakan strategi penting yang efektif bagi organisasi dalam mendorong profesionalisme kerja pegawai. Dalam rangka mewujudkan budaya organisasi yang cocok diterapkan pada sebuah organisasi, maka diperlukan adanya dukungan dan partisipasi dari semua anggota yang ada dalam lingkup organisasi tersebut. Para pegawai membentuk persepsi keseluruhan berdasarkan karakteristik budaya organisasi yang antara lain meliputi inovasi, kemantapan, kepedulian, orientasi hasil, perilaku pemimpin, orientasi tim, karakteristik tersebut terdapat dalam organisasi mereka. Persepsi pegawai mengenai kenyataan terhadap budaya organisasinya menjadi dasar pegawai berperilaku. Dari persepsi ini memunculkan suatu tanggapan berupa dukungan pada karakrteristik organisasi yang selanjutnya mempengaruhi profesionalisme 
kerja pegawai. Profesionalisme pegawai sangat ditentukan oleh tingkat kemampuan pegawai yang tercermin melalui perilakunya sehari - hari dalam organisasi. Profesionalisme adalah kompetensi untuk melaksanakan tugas dan fungsinya secara baik dan benar dan juga komitmen dari para anggota dari sebuah profesi untuk meningkatkan kemampuan dari seorang pegawai. Tingkat profesionalisme kerja pegawai yang tinggi akan lebih cepat mengarah kepada pencapaian tujuan organisasi yang telah direncanakan sebelumnya, sebaliknya apabila tingkat profesionalisme kerja pegawai rendah maka kecenderungan tujuan organisasi yang ingin dicapai akan lambat bahkan menyimpang dari rencana semula. Profesionalisme kerja pegawai ditentukan oleh keberhasilan budaya organisasi instansi atau lembaga yang dimilikinya.

Keberhasilan mengelola organisasi tidak lagi hanya ditentukan oleh keberhasilan prinsip-prinsip organisasi seperti planning, organizing, actuating, dan controlling akan tetapi ada faktor lain yang lebih menentukan keberhasilan instansi/organisasi mencapai tujuannya. Faktor tersebut adalah budaya organisasi instansi atau lembaga tersebut. Budaya organisasi secara realistis mempengaruhi profesionalisme kerja pegawai. Kesadaran pemimpin organisasi ataupun pegawai terhadap pengaruh budaya organisasi instansi/lembaga dapat memberikan semangat yang kuat untuk mempertahankan, memelihara, dan mengembangkan budaya organisasi tersebut yang merupakan daya dorong yang kuat untuk kemajuan organisasi instansi/lembaga. Budaya organisasi instansi/lembaga yang kuat akan menumbuhkembangkan rasa tanggung jawab yang besar dalam diri pegawai sehingga mampu memotivasi untuk menampilkan profesionalisme yang paling memuaskan, mencapai tujuan yang lebih baik, dan pada gilirannya akan memotivasi seluruh anggotanya untuk meningkatkan profesionalisme kerjanya. Namun dalam pelaksanaanya, jika budaya organisasi yang dimiliki Instansi atau lembaga tersebut kuat akan berpengaruh terhadap peningkatkan profesionalisme kerja pegawai dan sebaliknya jika budaya organisasi yang dimiliki oleh instansi atau organisasi tersebut lemah akan berpengaruh terhadap penurunan profesionalisme kerja. Maka dari itu dalam penelitian ini yang menjadi obyek penelitian adalah pengaruh budaya organisasi terhadap profesionalisme kerja pegawai. Hal ini disebabkan karena peneliti berasumsi bahwa budaya organisasi yang diterapkan dalam suatu instansi/organisasi manapun sangat mempengaruhi profesionalisme kerja pegawai, karena budaya organisasi dapat menjadi pedoman dasar bagi para pegawai untuk berprilaku dan berinteraksi di dalam instansi atau organisasi tersebut.

Pariwisata merupakan sektor industri yang sangat berkembang pesat di negara kita, selain itu pariwisata adalah salah satu sektor yang meningkatkan taraf perekonomian baik itu pendapatan negara maupun pendapatan daerah, sehingga tidak diragukan lagi apabila industri ini menjadi salah satu sektor yang kini mulai banyak diminati oleh para investor. Di Negara kita, salah satu provinsi yang memiliki berbagai kawasan wisata yakni Provinsi Jawa Barat, provinsi yang beribu kotakan Bandung ini memiliki banyak kawasan wisata yang sedang berkembang dengan pesat, selain itu Jawa Barat juga memiliki banyak kawasan yang berpotensi untuk dijadikan sebagai kawasan wisata. Jawa Barat merupakan 
salah satu provinsi yang memiliki penduduk terbanyak di Negara kita dan memiliki 3 suku suku asli, yakni suku Betawi, suku Sunda dan suku Jawa sehingga tidak hanya wisatawan domestik, wisatawan mancanegara menjadikan Provinsi Jawa Barat sebagai salah satu destinasi untuk dijadikan kawasan wisata yang ingin dikunjungi karena selain memiliki berbagai kebudayaan dan destinasi wisata yang beragam, berbagai kawasan wisata di Jawa Barat juga sangat menarik.

Resort merupakan salah satu perusahaan yang bergerak di industri pariwisata dengan kelengkapan berbagai jasa dan memiliki keterpaduan fasilitas yang satu sama lainnya saling menunjang. Resort juga merupakan salah satu destinasi wisatawan yang cukup banyak diminati karena berbeda dengan hotel, resort menyediakan pelayanan sekaligus fasilitas yang sangat lengkap sehingga wisatawan tidak hanya menginap tetapi juga bisa menikmati berbagai fasilitas yang tersedia, mulai dari penyediaan kamar hotel, penyediaan akomodasi, jasa makanan dan minuman, penyelenggara kegiatan hiburan dan rekreasi, objek daya tarik wisata, serta jasa souvenir. Resort memiliki konsep, yakni berdiri di kawasan remot area yang memperhatikan lokasi, karakter, perencanaan dan servis. Resort itu sendiri harus memiliki konsep dan tema, selain itu resort mengacu pada segi alam dan kebudayaan, adanya zona-zona pemisah dan fasilitas yang berstandar. Resort memiliki tujuan tidak hanya sebagai tempat berwisata tetapi juga melayani tamu dengan fasilitas yang lengkap sehingga tamu merasa nyaman dan merasa seperti tinggal ditempat sendiri. Oleh karena itu, resort menjadi salah satu tujuan wisatawan untuk berlibur karena selain fasilitasnya yang lengkap dan pelayanannya yang menyenangkan.

Salah satu tujuan dalam industri pariwisata adalah tercapainya kepuasan konsumen, begitu pula dengan PT sari ater hotel dan resort, selain menyediakan berbagai macam fasilitas yang lengkap PT Sari Ater hotel dan Resort juga memberikan pelayanan kepada wisatawan sebagai konsumen, ini dikarenakan hal yang paling penting dalam sebuah usaha (Resort) adalah bagaimana kualitas pelayanan yang diberikan oleh pihak managemen kepada konsumen (wisatawan), selain itu tingkat keberhasilan sebuah resort juga bergantung kepada kepuasan konsumen yang telah dicapai selama berkunjung ke PT Sari Ater Hotel dan Resort. Agar kepuasan konsumen ini dapat tercapai, maka kualitas terhadap pelayanan dan fasilitas, serta tingkat kemampuan sembar daya manusia (SDM) yang ikut bertanggung jawab dalam pengelolaannya haruslah terkelola dengan baik. Sari Ater Hot Spring Resort Hotel dan Rekreasi adalah tempat pemandian yang biasa dipergunakan oleh masyarakat sekitar Desa Ciater, Palasari dan Nagrak. Namun setelah seorang ahli berkebangsaan Belanda menemukan khasiat yang terdapat dalam air panas alam tersebut untuk menyembuhkan berbagai macam penyakit khususnya penyakit kulit, maka mulailah berdatangan orang dari berbagai daerah untuk datang mandi sambil berobat ke Ciater.

Berdasarkan informasi yang kita peroleh terdapat permasalahan, Hal ini dapat dilihat dari indikator diantaranya sebagai berikut: 
- Dengan kondisi Covid 19 ditemui keluhan sebagian karyawan mengeluh dengan adanya perubahan gaji yang diterima; hal ini menyebabkan kurangnya loyalitas karyawan terhadap perusahaan.

- Belum optimalnya penerapan Standar Oprasional Prosedur (SOP) terhadap karyawan karena pembinaan dan pengawasan di masa Covid 19 tidak optimal.

Dengan fenomena-fenomena tersebut peneliti tertarik untuk melakukan penelitian dengan judul : Budaya Organisasi Dalam Pelayanan Wisatawan Menghadapi Adaptasi Kebiasaan Baru (AKB) Pada Pt. Sari Ater Hotel \& Resort.

\section{Kerangka Teori}

Menurut Stephen. P. Robbins dan Mary Coulter (2011:5) pengertian manajemen adalah untuk mengkoordinasikan kegiatan kerja sehingga mereka menyelesaikannya secara efektif dan efisien dengan melalui kerja sama. Menurut Hasibuan (2010:2), “pengertian management adalah suatu ilmu dan seni yang mengatur proses pemanfaatan sumber daya manusia dan sumber daya lainya secara efektif dan efisien untuk mencapai suatu tujuan tertentu. Hasibuan (2003:10), "manajemen sumber daya manusia adalah sebagai penarikan, seleksi, pengembangan, penggunaan, dan pemeliharaan sumber daya manusia oleh organisasi" . Jadi menurut pengertian diatas bahwasanya sumber daya manusia adalah asset utama dalam perusahaan, tanpa adanya sumber daya manusia sebuah organisasi perusahaan tidak akan berjalan. Disamping itu, manajemen sumber daya manusia pula tidak dapat dijalankan dengan sendirinya, agar mendapatkan hasil yang maksimal dan dapat mencapai tujuan yang telah ditetapkan bersama dalam suatu organsasi maka harus adanya kerja sama antara anggota perusahaan.

\section{Budaya Organisasi}

Robbins (2008:11) Mengungkapkan “ Perilaku organisasi adalah bidang studi yang menyelidiki pengaruh yang dimiliki oleh individu, kelompok, dan struktur terhadap perilaku dalam organisasi, yang bertujuan menerapkan ilmu pengetahuan semacam ini guna meningkatkan keefektifan suatu organisasi". Perilaku organisasi adalah sebuah bidang studi khusus yang mempunyai pokok ilmu pengetahuan yang umum. Perilaku organisasi mengajarkan tiga faktor penentu perilaku dalam organisasi: individu, kelompok, dan struktur. Selain itu, perilaku organisasi menerapkan ilmu pengetahuan yang diperoleh tentang individu, kelompok, dan pengaruh dari struktur terhadapa perilaku untuk membuat organisasi bekerja secara lebih efektif. Budaya organisasi merupakat perekat bagi semua hal dalam suatu organisasi. Budaya organisasi adalah cara orang melakukan sesuatu dalam suatu organisasi. Budaya organisasi merupakan hal penting dalam pertumbuhan suatu organisasi karena budaya di dalamnya mampu merangsang semangat kerja sumber daya manusia sehingga mampu meningkatkan kinerja organisasi. Budaya organisasi akan mendorong sumber daya manusia yang ada didalamnya sehingga dapat menimbulkan rasa percaya diri dan mendorong mereka berfikir positif tentang mereka dan organisasinya. 
Menurut James L Gibson, John M. Ivancevich, dan James H. Donnelly Jr ( 2010 : 17 ) memberikan pengertian budaya organisasi sebagai apa yang dirasakan pekerja dan bagaimana persepsi ini menciptakan pola keyakinan, nilai-nilai, dan harapan.

Dari definisi tersebut dapat disimpulkan bahwasanya budaya organisasi itu adalah sesuatu hal atau aktivitas yang sudah rutin dilakukan dalam suatu kegiatan organisasi yang dilakukan secara teru-menerus dan pada akhirnya menjadi suatu kebiasaan yang sudah diterapkan dalam suatu organisasi tersebut, dan seiring berjalannya waktu kebiasaan tersebut akan menimbulkan persepsi dan pola keyakinan, rasa memiliki, percaya diri, dan akan menimbulkan harapan akan tercapainya suatu tujuan yang telah ditetapkan secara bersama yang nantinya akan dicapai secara bersama-sama oleh seluruh anggota yang ada dalam organisasi tersebut. Sehingga, apabila telah munculnya harapan dari setiap anggota maka akan timbul rasa semangat dan pola fikir yang positif bagi dirinya dan demi berlangsungnya pertumbuhan organisasinya.

Budaya organisasi menurut Stephen P. Robbins (2010:17) adalah sebuah persepsi umum yang dipegang oleh anggota organisasi, suatu sistem tentang keberartian bersama. Budaya organisasi berkepentingan dengan bagaimana pekerja merasakan karakteristik suatu budaya organisasi, tidak dengan apakah seperti mereka atau tidak. Dari definisi diatas dapat disimpulkan bahwasuatu budaya organisasi adalah filosofi perusahaan yang memuat keyakinan, dan nilainilai di dalamnya yang menjadi karakteristik atau jati diri bagi perusahaan tersebut.

Budaya organisasi merupakan suatu kekuatan sosial yang tidak tampak, yang dapat menggerakan orang-orang dalam suatu organisasi untuk melakukan aktivitas kerja. Secara tidak sadar sebenarnya setiap orang mempelajari budaya yang berlaku dalam organisasinya. Apalagi apabila ia sebagai orang baru maka ia harus mampu mempelajari budaya yang berlaku dalam organisasinya seperti apa saja yang dilarang untuk dilakukan dan apa yang diwajibkan, juga apa saja yang baik dilakukan dan yang buruk untuk dilakukan, apa saja yang benar dan sebaliknya apa saja yang salah, maka sebagai orang yang baru bergabung dalam suatu organisasi harus mampu mempelajari dan menyesuaikan dirinya dengan lingkungan yang ada disekitarnya agar mampu diterima dan bertahan dilingkungannya.

Budaya organisasi yang kuat akan mendukung tujuan-tujuan perusahaan, dan sebaliknya budaya organanisasi yang lemah akan menghambat pertumbuhan suatu perusahaan. Dalam suatu perusahaan yang budaya organanisasina kuat, nilai-nilai bersama dipahami secara mendalam, dianut, dan diperjuangkan oleh sebagian besar para anggota organisasi (karyawan perusahaan).

Budaya organisasi adalah suatu konsep yang sangat bervariasi, terbukti dari adanya sekian banyak definisi yang sangat berbeda-beda yang dapat ditmukan dalam kepustakaan. Hal ini disebabkan oleh berbagai pandangan, pendekatan, minat masing-masing yang berkepentingan dari berbagai kalangan akademisi maupun praktisi. Disamping itu juga karena sumbernya, yaitu disiplin antropologi, hingga sekarang belum menghasilkan satu definisi yang 
dapat diterima oleh para peminat.atau para pakar dalam bidang ini (Koentjaraningrat, 2010). Suatu tinjauan yang kritikal terhadap kepustakaan mengungkapkan bahwa pengertian budaya yang berdasar atas empiri dalam perangkat organisasi masih sangat jarang, dan jika ada ternyata belum memuaskan. Dari sisi fungsi, budaya organisasi memiliki beberapa fungsi menurut (Robbins, 2010) yaitu:

1. Budaya mempunyai suatu peran pembeda. Hal itu berarti bahwa budaya kerja menciptakan pembedaan yang jelas antara satu organisasi dengan yang lain.

2. Budaya organisasi membawa suatu rasa identitas bagi anggota-anggota organisasi.

3. Budaya organisasi mempermudah timbul pertumbuhan komitmen pada sesuatu yang lebih luas daripada kepentingan diri individual.

4. Budaya organisasi meningkatkan kemantapan sistem sosial.

Dalam hubungannya dengan segi sosial, budaya berfungsi sebagai perekat sosial yang membantu mempersatukan organisasi itu dengan memberikan standar standar yang tepat untuk apa yang harus dikatakan dan dilakukan oleh para karyawan. Setiap organisasi memiliki definisi yang berbeda-beda mengenai budaya organisasi. Menurut Robbins (2010 : 24) Budaya organisasi merupakan system nilai bersama dalam suatu organisasi yang menentukan tingkatan bagaimana para karyawan melakukan kegiatan untuk mencapai tujuan organisasi. Dengan memeahami dan menyadari arti pentingnya budaya organisasi bagi setiap individu, maka hendaknya hal tersebut mendorong para manajer untuk menciptakakn kultur yang menekankan pada interpersonal relationship yang tentunya juga akan lebih menarik bagi karyawan dibandingkan dengan work task. Menurut Robbins ( 2010:26 ), ada sepuluh karakteristik kunci yang merupakan inti dari budaya organisasi, yaitu :

1. Member Identity ( Identitas Anggota), yaitu dimana identitas anggota dalam suatu organisasi secara keseluruhan, dibandingkan dengan identitas dalam kelompok kerja atau bidang profesi masing-masing.

2. Group Emphasis ( Penekanan Kelompok), yaitu seberapa besar aktifitas kerja bersama lebih ditekankan dibandingkan kerja individu.

3. People Focus ( Fokus ), yaitu seberapa jauh keputusan manajemen yang diambil untuk mempertimbangkan keputusan tersebut terhadap anggota organisasi.

4. Unit Intergration ( Unit Integrasi ), yaitu seberapa jauh unit-unit di dalam organisasi dikondisikan untuk beroperasi secara bersama-sama.

5. Control ( Pengawasan ), yaituseberapa banyak aturan, peraturan, dana pengawasan langsung yang digunakan untuk mengawasi dan mengendalikan perilaku karyawan.

6. Risk Tolerance ( Toleransi Resiko ), yaitu besarnya dorongan terhadap karyawan untuk lebih agresif, inovatif, dan berani mengambil resiko.

7. Reward Criteria ( Kriteria Penghargaan ), yaitu seberapa besar imbalan dialokasikan sesuai dengan kinerja karyawan, dibandingkan alokasi berdasarkan senioritas, favoritism, atau factor bukan kinerja lainnya.

8. Conflict Tolerance ( Toleransi Konflik), yaitu seberapa besar karyawan didorong untuk bersikap terbuka terhadap konflik dan kritik. 
9. Means-ends Orientation ( Cara Berorientasi), yaitu seberapa besar manajemen lebih menekankan pada penyebab atau hasil dibandingkan pada teknik atau proses yang digunakan untuk mengembangkan hasil.

10. Open-sistem Focus ( Sistem yang Terbuka), yaitu seberapa besar pengawasan organisasi dan respon yang diberikan untuk mengubah lingkungan eksternal.

Sedangkan karakteristik budaya organisasi menurut Victor Tan (2010:47) yaitu sebagai berikut:

1. Individual Initiative (inisiatif individual)

Menunjukan tingkat tanggung jawab, kebebasan dan ketidaktergantungan yang dimili individu.

2. Risk Tolerance ( toleransi terhadap resiko)

Suatu keadaan dimana pekerja didorong mengambil resiko, menjadi agresif dan inovatif.

3. Direction (arah)

Merupakan kemampuan organisasi menciptakan sasaran yang jelas dan menepatkan harapan kinerja.

4. Integration (integrasi)

Suatu tingkatan dimana suatu unit organisasi didorong untuk bekerja dengan cara terkoordinasi.

5. Management Support (dukungan manajemen)

Manajer menyediakan komunikasi yang jelas, bantuan, dukungankepada bawahannya.

6. Control (pengawasan)

Merupakan jumlah aturan dan ketentuan dan jumlah pengawasan langsung yang dipergunakan untuk melihat dan mengawasi perilaku karyawan.S

7. Identity (identitas)

Suatu tingkatan dimana anggota mengidentifikasi dengan organisasi secara keseluruhan, daripada dengan kelompok kerja tertentu atau bidang keahlian professional tertentu.

8. Reward System (sistem pengarahan)

Dimana alokasi reward (kenaikan gaji upah atau upah), didasarkan pada kriteria alokasi biaya didasarkan pada kriteria kinerja, sebagai lawan dari senioritas atau favoritism.

9. Conflict Tolerance (tolersnsi terhadap konflik)

Suatu tingkatan dimana pekerja didorong untuk menyiram konflik dan kritikan secara terbuka.

10. Communication Pattern (pola komunikasi)

Suatu tingkatan dimana komunikasi dibatasipada hierarki formal dimana komunikasi organisasi dibatasi pada kewenangan hierarki formal.

Selain karakteristik-karakteristik diatas, Jerrald Greenberg dan Robert A. Baron ( 2010:65 ) memerhatikan adanya tiga sumber yang dapat menciptakan budaya organisasi, yaitu :

1. Company Founder (Pendiri Perusahaan) 
Budaya organisasi dapat dilacak, paling tidak sebagian, pada pendiri perusahaan. Individu ini sering mempunyai kepribadian dinamis, Strong Values, dan visi yang jelas tentang bagaimana organisasiharus bekerja. Karena dia memainkan peran penting dalam menerima staf pada awalnya, maka sikap dan nilai-nilai siap disampaikan pada pekerja baru. Sebagai hasilnya, pandangan mereka diterima orang dalam organisasi dan tepat seperti yang diinginkan selama pendiri masih berperan.

2. Eksperience with the environment (pengalaman dengan lingkungan )

Budaya organisasi sering berkeembang diluar pengalaman organisasi dengan lingkungan eksternal. Setiap organisasi harus menemukan ceruk atau celah bagi dirinya dalam industry dan di pasar.

3. Contact with other ( kontak dengan orang lain )Budaya organisasi juga berkembang diluar kontak antara kelompok individu dalam organisasi yang datang berbagi interprestasi kejadian dan tindakan dalam organisasi.

Perilaku dalam budaya organisasi mendasari dan menjadi kontributor utama pada budayanya. Perilaku individu mendorong pada perilaku organisasi dan akhirnya akan mempengaruhi kinerja organisasi. Perilaku organisasi dicerminkan dalam cara di mana pekerja, pelanggan, atasan, bawahan saling berinteraksi. Di abad dimana bekerja dibantu oleh teknologi. Tujuan, sasaran, dan kebijakan organisasi mempengaruhi bagaimana orang berperilaku dalam organisasi. Organisasi yang hanya mempunyai sedikit tuntutan kepada pekerja membuat mereka merasakan kekurangan urgensi, inovasi, dan ambisi untuk sukses. Memahami perilaku organisasi dan pekerjaannya adalah kritis untuk mengerti budaya dan memahami setiap inisiatif perubahan.

\section{Metode Penelitian}

Dalam penelitian ini, penulis menggunakan metode kualitatif, yang berbasis pada informasi atau kenyataan yang terjadi di lapangan Adapun prosedur-prosedur pada metode kualitatif yaitu: pengambilan informan secara sengaja, pengumpulan data terbuka, analisis teks atau gambar, penyajian informasi dalam bentuk gambar dan tabel, serta interprestasi pribadi atas temuan-temuan. Desain penelitian ini merupakan penelitian deskriptif kualitatif. Penelitian ini dipilih karena untuk menyajikan data secara sistematis, faktual dan akurat mengenai fakta-fakta yang ada dilapangan. Penelitian deskriptif kualitatif bertujuan untuk menggambarkan, melukiskan, menerangkan, menjelaskan dan menjawab secara lebih rinci permasalahan yang akan diteliti dengan mempelajari semaksimal mungkin seorang individu, atau kelompok atau suatu kejadian. Dalam penelitian kualitatif manusia merupakan instrument penelitian dan hasil penulisannya berupa kata - kata atau pernyataan yang sesuai dengan keadaan yang sebenarnya. Penelitian ini menggunakan desain penelitian deskriptif kualitatif bertujuan untuk menggali fakta dan memastikan kebenaran data yang ada di lapangan mengenai Budaya Organisasi Dalam Pelayanan Wisatawan Menghadapi Adaptasi Kebiasaan Baru (Akb) PT. Sariater Hotel \& Resort. 


\section{Hasil dan Pembahasan}

\section{Gambaran Umum Perusahaan}

Pada awalnya Tempat Wisata Air Panas Alam Ciater yang sekarang lebih dikenal dengan sebutan Sari ater Hot Spring Resort adalah Tempat pemandian yang biasa dipergunakan oleh masyarakat sekitar Ciater,Palasari dan Nagrak. Pada tahun 1968 Pemda Kabupaten Subang melalui PU Kabupaten bekerjasama dengan Dispenda pelahan-lahan mulai menggarap sumber air panas alam ciater sebagai objek wisata. Sebagai manajer pertama ditetapkan Bapak Sahro dari PU Kabupaten sedangkan jumlah karyawan pada saat itu kurang lebih hanya 11 orang. Pada tahun 1972 PPN DWIKORA IV (sekarang ptpn XIII Ciater) membuat 1 buah bangunan untuk kamar mandi dan pintu gerbang berbentuk joglo yang lengkap dengan kantor dan loket penjualan tiket.

Pada tanggal 20 maret 1974 Pemda TK II Kabupaten Subang menyerahkan pengelolaan Objek Wisata Air Panas Ciater kepada PT.Sari Ater yang dipimpin oleh Bapak H.A SOEWARMA. manajer pertama yang dipercayakan oleh PT.Sari Ater untuk memimpin pengelolaan objek wisata Air panas alam Ciater adalah Bapak Gautama, alm(thn 1974 s/d 1975). Jumalah karyawan yang ada pada saat itu kurang lebih 16 orang dan Seluruh area wisata seluas $7.335 \mathrm{H}$, yang dikelola dibenahi dan dibuatkan pagar pembatas dari kawat berduri. Pada Tahun 1976, dimulai pembangunan Restaurant Dayang Sumbi, Bungalows kabayan, sarana parkir dan rekreasi kolam perahu. Pimpinan pada daat itu dipercayakan kepada manager ketiga yaitu Bapak J.R. Iskandar, Alm(tahun 1976 s/d 1977). Pada tahun 1977 pimpinan usaha dipercayakan kepada Mr.Evandra alias Bapak Muhammad Effendi seorang ahli berkebangsaan italy (tahun 1977 s/d 1979) dan jumlah karyawan telah meningkat menjadi kurang lebih 70 orang.

Pada tahun 1980 mulai pembenahan dan pengembangan sarana dan prasarana secara besar-besaran, pada saat itu dibangun : Kolam Renang bawah atau mayangsari II, Bungalow Jammbu, Area rekreasi sampai curug Jodo. dengan sumber dana dari BAPINDO. manager ke IV yang memimpin saat itu adalah Bapak Anton Tirto (tahun 1979 s/d 1985) sedangkan karyawan berjumlah kurang lebih 100 orang. Manager ke VI dijabat oleh Bapak Ruby dan pada tahun 1987 pimpinan diserahkan kepada Bapak Herrie Hermanni dengan jabatan sebagai Operational Manager. Pada tanggal 24 oktober 1994 dilakukan Restrukturisasi organisasi dan ditetapkan seorang General Manager untuk memimpin hotel dan objek wisata Sari Ater dengan nama Sari Ater Hot Spring Resort. Sebagai general manager yang pertama ditetapkan Bapak Herrie Hermanni dengan jumlah karyawan pada saat itu 333 orang sedangkan luas kawasan hotel dan objek wisata telah menjadi 32 Ha. Pada tahun 1998 dibangun kembali satu fasilitas air panas alam di area rekreasi dengan nama Pulosari, dengan daya tampung untuk 500 orang dan diresmikan oleh Bupati tingkat II subang Bapak Drs. H.Abdul Wahyan tepatnya pada tanggal 25 Juli 1998.

\section{Budaya Organisasi Dalam Pelayanan Wisatawan Menghadapi Adaptasi Kebiasaan Baru (AKB) Pada Pt. Sari Ater Hotel \& Resort}

Karyawan merupakan sumber daya paling penting yang dimliki oleh perusahaan umtuk meningkatkan kinerja perusahaan. Pelayanan yang diberikan 
oleh perusahaan kepada para masyarakat melalui sumber dayanya yang apabila masyarakat merasa puas dengan pelayanan yang diberikan oleh perusahaan maka akan berdampak baik bagi perusahaan. Seperti yang kita ketahui bahwa PT Sariater Hotel \& Resort sedang meningkatkan budaya organisasi yang ada PT Sariater Hotel \& Resort ini, budaya organisasi yang baik akan mempengaruhi perkembangan perusahaan.

Budaya organisasi yang baik dapat memberikan dampak baik pula kepada karyawan maupun perusahaannya, adanya kepercaya diri dan rasa memiliki dari setiap karyawan perusahaan akan menumbuhkan rasa bangga bagi seluruh anggota organisasi yang berada dalam organisasi tersebut, maka apabila seluruh anggota organisasi telah memiliki rasa bangga akan tempat dimana ia bekerja maka hal ini akan berpengaruh kepada berkembangnya suatu perusahaan. Dalam kajian ini bahwa Budaya organisasi di PT Sariater \& Resort dapat diukur melalui indikator sebagai berikut:

a) Member Identity (Identitas Anggota)

b) Group Emphasis (Penekanan Kelompok)

c) People Focus (Fokus)

d) Unit Integration (Unit Integrasi)

e) Control (Pengawasan)

f) Risk Tolerance (Toleransi Resiko)

g) Reward Criteria (Kriteria Penghargaan)

h) Conflict Tolerance ( Toleransi Konflik)

i) Meands-ends Orientation (Cara Berorientasi)

j) Open-sistem Focus (Sistem yang Terbuka)

Secara per sub bahasan dapat dikaji sebagai berikut :

\section{Member Identity (Identitas Anggota)}

Yang dimaksud dengan identitas anggota adalah dimana identitas ini dalam suatu organisasi secara keseluruhan, dibandingkan dengan identitas dalam kelompok kerja atau bidang profesi masing-masing.Untuk mengetahui bagaimana perusahaan mamandang seluruh karyawan yang ada di PT Sariater Hotel \& Resort tersebut, misalnya apakah dibedakan dari jenjang pendidikan, atau adanya perbedaan perlakuan kepada setiap karyawan, maka untuk mengetahui hal tersebut peneliti mengajukan beberapa pertanyaan yang harus mereka jawab, pertanyaannya sebagai berikut : Apakah ada perbedaan perlakuan antara individu yang satu dengan individu yang lainnya dalam perusahaan ini?

Untuk mengetahui apakah adanya perbedan perlakuan terhadap karyawan yaitu dengan pertanyaan sebagai berikut: Anda sebagai karyawan apakah merasa adanya perbedaan perlakuan antara karyawan yang satu dengan karyawan lainnya, misalnya antara karyawan lama dengan karyawan yang baru ? jawaban wawancara:" yang saya rasakan tidak ada hal seperti itu, pihak organisasi menyama ratakan antara satu karyawan dengan karyawan lainnya, hanya saja lebih memperhatikan karyawan baru yang belum terlalu faham akan pekerjaannya". Untuk mengetahui valid tidaknya maka dilakukan lagi beberapa pertanyaan kepada karyawan lain yaitu : Untuk bekerja disini apakah ada 
persyaratan khusus untuk menjadi karyawan ? jawabannya : "minimal SMA/sederajat untuk sekarang, tapi ada beberapa karyawan yang hanya lulusan SMP itu hanya karyawan yang sudah lama disininya" . Dalam sebuah organisasi setiap karyawan wajib mendapatkan perlakuan yang baik dari tempat dimana ia bekerja. Salah satu syaratya adalah memiliki pendidikan setinggi mungkin untuk mendapatkan kehidupan yang lebih layak. Dengan pendidikan tinggi akan lebih mudah untuk menjalani dan memahami sesuatu baru dalam dunia pekerjaan.

Berdasarkan hasil observasi yang dilakukan peneliti bahwa benar perusahaan memberikan persyaratan khusus bagi siapa saja yang ingin menjadi karyawan PT Sariater Hotel \& Resort , minimal SMA/Sederajat, untuk yang akan mengisi bagian administrasi itu bisa semua jurusan dan terkhusus.

\section{Group Emphasis (Penekanan dalam Kelompok)}

Maksud dari penekanan kelompok dalam budaya organisasi adalah seberapa besar aktifitas kerja bersama lebih ditekankan dibandingkan kerja masing-masing atau secara individu. Dalam suatu organisasi kerja bersama lebih penting dibandingkan kerja masing-masing, dengan kerja bersama pekerjaan akan lebih mudah dilaksanakan dan tidak membutuhkan waktu terlalu lama, selain itu pekerjaan akan lebih ringan dibandingkan dikerjakan masing-masing. Budaya organisasi yang baik tentu tidak hanya menguntungkan perusahaan, akan tetapi memberikan kepuasan bagi setiap kalangan yang menggunakan jasa kesehatan ini, organisasi yang terorganisir akan menciptakan kinerja yang baik pula. Apabila pelayanan baik maka akan menjadi daya tarik bagi setiap kalangan untuk menggunakan jasa pelayanan kesehatan PT Sariater Hotel \& Resort ini dibandingkan perusahaan yang lainnya.

Untuk mengetahui bagaimana kinerja di perusaaan ini maka peneliti mengajukan beberapa pertanyaan sebagai berikut : Bagaimana cara organisasi untuk lebih menekankan agar karyawan lebih bekerja secara bersama dibandingkan masing-masing ?. Kutipan wawancara dengan bagian SDM dan Umum yaitu bapak Benny : "Kami selaku pihak manajemen yang bertanggung jawab dalam mengorganisisr SDM memberikan pengertian dan pemahaman bahwasanya setiap karyawan agar bekerja sama antara yang satu dengan yang lainnya, guna memudahkan tugas dan pekerjaan yang diberikan, ya tapi tergantung ya tidak semuanya harus bekerja bersama ada beberapa bagian yang memang dituntut untuk lebih fokus pada pekerjaan masing-masing" .

Berdasarkan hasil observasi yang dilakukan peneliti bahwa benar perusahaan lebih menekankan pada kerja sama team dibandingkan individu, mengapa karena di perusahaan manapun kerja team sangat dibutuhkan untuk menyelesaikan segala pekerjaan, dengan adanya kerja team maka akan lebih mempersingkat waktu dalam melaksanakan tugas dan tanggung jawab.Hal ini dapat berdampak positif juga pada hasil akhirnya, seperti kinerja yang baik dan meningkat.

Berdasarkan uraian diatas peneliti dapat menyimpulkan bahwa PT Sariater \& Resort Subang, mengarahkan dan menekankan seluruh karyawannya untuk bekerja secara team dan tidak individu, karena kerja team lebih baik dibandingkan dengan individu. Karyawan yang menjalankan pekerjaan dan 


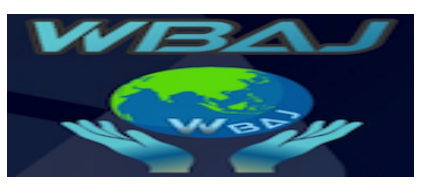

tanggungjawabnya dilakukan secara kerja team maka akan lebih mudah dan cepat dalam penyelesaian pekerjaannya.

\section{People Focus (Fokus Anggota)}

Yaitu seberapa jauh keputusan-keputusan manajemen yang diambil untuk mempertimbangkan keputusan tersebut kepada anggota organisasi. Setiap keputusan yang diambil oleh manajemen harus mempertimbangkan apakah karyawan mampu dan nyaman menjalankannya, atau malah merasa terbebani oleh aturan-aturan yang perusahaan berikan.Untuk mengetahui bagaimana mengenai keputusan-keputusan yang diambil oleh manajamen terhadap anggota organisasi, maka penulis mengajukan beberapa pertanyaan yang harus mereka jawab, pertanyaannya sebagai berikut : Kebijakan apa yang akan organisasi berikan apabila ada karyawan yang memiliki disiplin buruk dalam mentaati peraturan perusahaan ?. Kutipan wawancara oleh bagian SDM dan Umum dikemuakakan diantaranya sebagai berikut : " pastinya kami menegur dan apa yang menyebabkan karyawan tersebut tidak mentaati peraturan yang sudah seharusnya ditaati bersama oleh anggota organisasi".

Pertanyaan berikutnya dengan responden yang sama, sebagai berikut : Apabila ada karyawan yang mendadak mengajukna pensiun dini apakah perusahaan akan langsung menyetujuinya atau ada kebijakan lain ? jawabannya : "soal pensiun dini kami disini jarang ada karyawan yang mengajukan pensiun dini, tapi bagi karyawan yang mengajukan hal tersebut terlebih dahulu kami menanyakan alasan mengapa mengajukan pensiun dini, dan masalah kebijakan tidak ada kebijakan khusus"

Pertanyaan selanjutnya diajukan informan, yaitu sebagai berikut: Apakah ada peraturan dari organisasi yang membebani karyawan saat melaksanakan pekerjaan, jawaban wawancara :"selama ini tidak ada peraturan yang terlalu membebani pekerjaan, ini sih peraturan normal pada umumnya" .

Berdasarkan hasil observasi yang dilakukan peneliti bahwa benar manajemen selalu mempertimbangkan setiap keputusan-keputusan yang akan diambil dan tidak bertindak semena-mena terhadap mengambil keputusan, selalu disesuaikan dengan kemampuan karyawannya.

Berdasarkan uraian diatas peneliti dapat menyimpulkan bahwa PT Sari Ater \& Resort Subang pihak manajemen sangat berhati-hati dan selalu mempertimbangkan setiap keputusan-keputusan yang akan dikeluarkan, tidak hanya baik bagi perusahaan saja akan tetapi membantu karyawan dalam mecapai setiap tujuan perusahaan secara maksimal dan setiap keputusan yang akan dikeluarkan selalu memikirkan keputusan-keputusan tersebut agar tidak membebani terhadap proses kerja karyawannya.

\section{Unit Integration (Unit Integrasi)}

Unit integrasi yaitu seberapa jauh unit-unit di dalam organisasi dikondisikan untuk beroperasi secara bersama-sama. Untuk mengetahui bagaimana mengenai kinerja unit integrasi di PT Sari Ater \& Resort Subang, 
maka diajukan beberapa pertanyaan yang harus mereka jawab, dengan pertanyaan sebagia berikut : Apakah setiap unit yang ada di dalam organisasi dikondisikan untuk bekerja secara bersama-sama ?. Kutipan wawancara dengan bagian SDM dan Umum yaitu : "tentu saja neng setiap unit dalam organisasi kami diarahkan untuk bekerja bersama-sama guna memberikan pelayanan terbaik kepada pihak yang menggunakan jasa pelayanan wisata di perusahaan kami". Pertanyaan berikutnya kepada responden yang sama,sebagai berikut : Bagaimana cara anda mengkoordinir agar setiap unit benar-benar saling bekerja sama dalam menjalankan pekerjaannya ? jawaban wawancara :"kami lakukan briefing bersama para ketua dari setiap unit, nanti biar ketua yang mengarahkan kepada anggota setiap unitnya". Selain itu kami ajukan beberapa pertanyaan kepada karyawan, dengan pertanyaan sebagai berikut : Apakah semua unit dalam organisasi diarahkan untuk bekerja sama atau hanya beberapa unit saja ? jawaban wawancara: "ya neng kalo setiap unit tidak bekerja sama tidak akan berjalan dengan baik pelayanannya"

Berdasarkan uraian diatas maka peneliti dapat menyimpulkan bahwa PT Sari Ater \& Resort Subang selalu mengarahkan setiap unit yang ada di dalam organisasi untuk selalu bekerja secara bersama, guna memberikan pelayan yang terbaik terhadap masyarakat yang telah percaya menggunakan jasa layanan kesehatan Rumah Sakit tersebut.

\section{Control (Pengawasan)}

Yaitu seberapa banyak aturan, peraturan, dan pengawasan langsung yang digunakan untuk mengawasi dan mengendalikan perilaku karyawan. Pengawasan yang baik dan dilakukan secara berkesinambungan akan membantu terhadap meningkatnya kinerja karyawan, karena pengawasan adalah hal penting yang harus ada dalam setiap manajemnen di dalam perusahaan manapun. Untuk mengetahui bagaimana mengenai pengawasan terhadap karyawan di PT Sari Ater \& Resort Subang, maka diajukan beberapa pertanyaan yang harus mereka jawab, yaitu sebagai berikut : Siapa saja yang bertanggung jawab dalam mengawasi setiap karyawan pada saat menjalankan tugasnya masing-masing ?. Kutipan wawancara dengan bagian SDM dan Umum yaitu :"kalo untuk yang bertanggung jawab ada kepala unit dari setiap unitnya" . Pertanyaan berbeda diajukan kepada responden yang sama, dengan pertanyaan sebagai berikut : Metode atau cara seperti apa yang dilakukan oleh organisasi untuk mengawasi setiap karyawan dalam menjalankan tugasnya ? jawabannya : "tidak ada metode khusus hanya saja tanggung jawab itu diberikan kepada kepala dari setiap unit, bagian SDM dan Umum hanya menerima laporan dan menindak lanjuti laporan dari setiap unit kerja"

Berdasarkan hasil observasi yang dilakukan peneliti bahwa benar perusahaan mengawasi setiap perilaku karyawannya pada saat bekerja, karena pengawasan sangat penting dalam suatu organisasi. Berdasarkan uraian diatas maka peneliti dapat menyimpulkan bahwa PT Sari Ater \& Resort Subang melakukan pengawasan terhadap perilaku karyawan dalam menjalankan tugasnya, sehingga karyawan lebih disiplin dan mentaati peraturan yang telah disepakati bersama. Namun masih belum maksimal dan hal ini dapat dilihat dari 
proses pengawasan tersebut tidak langsung diawasi oleh bagian SDM dan Umum akan tetapi pengawasan lebih intens dilakukan oleh kepala dari setiap unitnya.

\section{Risk Tolerance (Toleransi Resiko)}

Yaitu seberapa besar dorongan terhadap karywan untuk lebih agresif, inovatif, dan berani mengabil resiko. Pada dasarnya dalam suatu organisasi perusahaan karywan atau SDM yang ada di dalamnya adalah modal utama berkembang tidaknya suatu perusahaan, bila SDM nya kreatif dan mau mengambil resiko maka hal ini akan melatih mental karyawan dalam proses menjalankan pekerjaannya. Untuk mengetahui bagaimana toleransi resiko yang ada di lapangan, maka penulis mengajukan beberapa pertanyaan yang harus merekajawab, dengan pertanyaan sebagai berikut : Apakah perusahaan memberikan kebebesan kepada karyawan untuk lebih berinovasi dan agresif pada saat bekerja ? jawabannya : Kutipan wawancara dengan bagian SDM dan Umum yaitu: "iya kami tidak membatasi perilaku karyawan selama itu masih dalam aturan yang berlaku". Pertanyaan berikutnya dengan responden yang sama, pertanyaan sebagai berikut : Bagaimana apabila ada karyawan yang bekerja secara monoton? jawaban wawancaranya :"selama ini belum ada yang seperti itu"

Berdasarkan hasil observasi yang dilakukan peneliti bahwa benar perusahaan memberikan kebebasan karyawan dalam berinovasi dan bekerja secara agresif. Hal ini dapat dilihat dari karyawan PT Sari Ater \& Resort Subang begitu ramah dan cepat dalam penanganan pasien. Berdasarkan uraian diatas peneliti dapat menyimpulkan bahwa PT Sari Ater \& Resort Subang tidak membatasi setiap karyawan dalam berperilaku atau berkomunikasi dengan karyawan lainnya dalam arti perusahaan memberikan kebebasan berperilaku kepada karyawan dalam menjalankan tugas dan tanggungjawabnya selama perilaku tersebut mentaati aturan yang telah disepakati bersama.

\section{Reward Criteria (Kriteria Penghargaan)}

Yang dimaksud dengan kriteria penghargaan adalah seberapa besar imbalan yang perusahaan berikan kepada karyawan apakah sesuai dengan kinerja atau tidak, dibandingkan dengan faktor berdasarkan senioritas atau yang lainnya. Penghargaan sangat penting dalam perusahaan, tujuannya untuk meningkatan semangat karyawan dalam bekerja, dan membangkitkan daya saingnya, sehngga karyawan lebih termotivasi. Untuk mengetahui apakah kriteria penghargaan di perusahaan sesua atau tidak, maka peneliti mengajukan beberapa pertanyaan kepada mereka yang harus mereka jawab, dengan pertanyaan sebagai berikut: Apakah perusahaan memeberikan upah/gaji sesuai dengan yang seharusnya karyawan dapatkan? Kutipan wawancara dengan bagian SDM dan Umum yaitu : "tentu saja kami memberikan imbalan yang sesuai dengan kinerja karyawan". Pertanyaan berbeda kepada responden yang sama, dengan pertanyaan sebagai berikut: Apakah perusahaan memberikan bonus kepada karyawan setiap tahunnya ? jawabannya : "iya selain dari THR 
ada bonus lain yang kami berikan kepada karyawan, seperti bila ada peningkatan terhadap perusahaan maka kami memberikan bonus kepada karyawan terkadang ada satu kali dalam satu tahun". Untuk mendapatkan data yang valid, maka penulis mengajukan beberapa pertanyaan kepada karyawan yaitu dengan pertanyaan sebagai berikut: Menurut anda apakah upah/gaji yang perusahaan berikan sudah sesuai dengan pekerjaan anda ? jawabannya :"untuk gaji sudah sesuai dengan yang seharusnya saya terima".

Berdasarkan hasil observasi yang dilakukan penulis bahwa benar perusahaan memberikan upah / gaji yang seharusnya karyawan terima. Karena upah/gaji adalah tujuan utama karyawan dalam pekerjaan, apabila upah/gaji nya dapat memuaskan karyawan maka dengan sendirinya akan tubuh loyalitas dalam diri karyawan.

Berdasarkan uraian diatas peneliti dapat menyimpulkan bahwa PT Sari Ater \& Resort Subang memberikan upah/gaji sebagai balas jasa terhadap karyawan, dan upah/gaji tersebut telah diberikan sesuai dengan yang seharusnya, disamping upah yang di dapat secara continoue karyawan juga mendapatkan bonus yang biasanya dua kali dalam setahun tergantung dari perkembangan dan omset yang didapatkan oleh Perusahaan selama periode tertentu.

\section{Conflict Tolerance (Toleransi Konflik)}

Toleransi konflik dapat dilihat dari seberapa besar karyawan di dorong untuk bersikap terbuka terhadap konflik dan kritik. Dalam setiap perusahaan akan terjadi konflik entah iru di dalam manajemen atau karyawan dengan karyawan, banyaknya jumlah karyawan akan membuat timbulnya persaingan antar karyawan, maka tidak asing lagi apabila terjadinya konflik dalam suatu pekerjaan, karena rasa ingin diakui oleh pimpinan dan ingin dipandang paing baik oleh pimpinan, maka dari itu untuk menghindari hal tersebut pihak manajemen telah menyiapkan kotak dan saran bagi siapa saja yang memiliki keluhan agar segera diungkapkan tidak dipendam secara pribadi yang nanti akan berdampak pada kinerja yang kurang maksimal. Untuk mengetahui bagaimana toleransi konflik yang ada di lapangan, maka peneliti mengajukan beberapa pertanyaan yang harus dijawab oleh mereka, dengan pertanyaan sebagai berikut : Apakah pernah terjadi konflik antara karyawan yang satu dengan yang lainnya?. Kutipan wawancara dengan bagian SDM dan Umum yaitu bapak Benny : "konflik dimanapun pasti pernah terjadi, pernah terjadi beberapa konflik antara karyawan hanya bisa di damaikan dengan kekeluargaan".

Pertanyaan berbeda dengan responden yang sama, yaitu dengan pertanyaan sebagai berikut : Biasanya konflik seperti apa yang pernah terjadi antara karyawn yang satu dengan karyawan yang lain? jawaban wawancaranya : "paling konflik urusan pribadi antar individu, tapi sudah saya peringatkan untuk tidak membawa masalah pribadi kedalam pekerjaan". Berdasarkan hasil observasi yang dilakukan penulis bahwa benar adanya keterbukaan karyawan terhadap konflik dan kritik. Contohnya Perusahaan membuat kotak dan saran khusus bagi karyawan yang kurang nyaman dalam bekerja dapat mengkritik 
atau memberi masukan kepada perusahaan apabila ada sesuatu yang mengganjal dalam menjalankan tugas pekerjaannya.

Berdasarkan uraian diatas peneliti dapat menyimpulkan bahwa dimanapun dalam perusahaan aka nada konflik antar karyawan yang satu dengan karyawan lainnya ataupun antar karyawan dengan pmpinan. Pernah terjadi konflik antar karyawan yang disebabkan oleh maslah pribadi dan hal tersebut tidak berlangsung lama dan dapat diselesaikan secara kekeluargaan.

\section{Means-ends Orientation (Cara Berorientasi)}

Maksudnya adalah seberapa besar manajemen lebih menekankan pada penyebab atau hasil, dibandingkan pada teknik atau proses yang digunakan untuk mengembangkan hasil. Untuk mengetahui cara berorentiasi di lapangan, maka peneliti mengajukan beberapa pertanyaan kepada mereka yang harus mereka jawab, dengan pertanyaan sebagai berikut : Apakah selalu diadakan evalusi kerja apabila adanya penurunan kinerja dari karyawan ?. Kutipan wawancara dengan bagian SDM dan Umum yaitu bapak Benny :"iya , tapi tidak semua karyawan hadir hanya kepala dari setiap unitnya saja yang kami kumpulkan"

Pertanyaan berbeda kepada responden yang sama, pertanyaannya : Metode atau cara apa yang organisasi gunakan untuk mengembangkan kinerja karyawan ? jawabannya : "biasanya kami melihat pada hasil akhir dan penyebabnya saja, misalnya kenapa bulan ini banyak pasien yang mengeluh terhadap pelayanan kami, nah kami evaluasi itu". Berdasarkan hasil observasi yang dilakukan peneliti bahwa benar perusahaan lebih menekankan kepada penyebab atau hasil akhir kinerja dibandingkan proses dalam mengerjakan pekerjaan tersebut. Hal tersebut dapat dilihat dari adanya evalusi dan briefing bagi kepala unit yang dilakukan satu minggu sekali.

Berdasarkan uraian diatas peneliti dapat menyimpulkan bahwa PT Sari Ater \& Resort Subang memberikan keleluasaan pada karyawan dalam bekerja untuk mencapai tujuan yang telah disepakati bersama, dengan cara fokus terhadap penyebab dan hasil dari pekerjaan yang dilakukan dibandingkan dengan proses pekerjaannya tersebut.

\section{Open-sisem Focus (Sistem Fokus Terbuka)}

Yaitu seberapa besar pengawasan organisasi dan respon yang diberikan untuk mengubah lingkungan eksternal. Untuk mengetahui bagaimana sistem yang terbuka dilapangan, maka peneliti mengajukan beberapa pertanyaan yang harus mereka jawab, dengan pertanyaan sebaga berikut : Hasil kerja karyawan dapat dilihat dari puas tidaknya masyarakat terhadap pelayanan yang diberikan, dengan cara apa organisasi mengetahu puas tidaknya pelayanan yang masyarakat dapatkan ? jawabannya : Kutipan waancara dengan bagian SDM dan Umum yaitu : "kami membuat kotak saran dan kritik pula untuk masyarakat yang merasa puas atau tidaknya terhadap pelayanan yang kami berikan" .Pertanyaan selanjutnya diajukan kepada salah satu karyawan di PT Sari Ater \& Resort Subang tersebut, yaitu dengan pertanyaan sebagai berikut: Apakah pernah terjadi protes atau keluhan dari masyarakat selama anda bertugas disini 
? jawabannya : "iya ada, tapi itu bukan kesalahan dari kami, ada satu wisatawan yang tidak antri saat di pintu masuk, lalu kami menegur untuk mengantri akhirnya terjadi adu mulut dan untungnya wisatawan tersebut diberikan pengertian bahwa semua yang datang ke poliklinik wajib mengantri" .Untuk mendapatkan data yang valid maka peneliti mengajukan pertanyaan kepada karyawan lain, yaitu dengan pertanyaan sebagai berikut : Apakah disediakan kotak kritik dan saran untuk masyarakat yang merasa tidak puas dalam pelayanan yang perusahaan berikan ? jawabannya :"iya ada" .

Berdasarkan hasil observasi yang dilakukan peneliti bahwa benar perusahaan sangat terbuka dengan sistem dan informasi tentang perusahaan terhadap karyawannya. Seperti contoh adanya interaksi antar pihak manajemen dengan masyarakat sekitar, seperti keamana perusahaan dalam menjalankan tugas dan aktifitasnya di lingkungan tersebut. Pengaruh lingkungan eksternal juga akan berdampak pada aktifitas perusahaan yang dijalankan. Contoh dahulu dilingkungan Rumah Sakit menggunakan jasa parker dari pihak luar (bukan karyawan perusahaan), akan tetapi untuk saat ini PT Sari Ater \& Resort Subang sudah memperbaiki hal tersebut maka untuk parkiran dikelola oleh Pihak PT Sari Ater \& Resort Subang.

Berdasarkan uraian diatas benar bahwasanya PT Sari Ater \& Resort Subang terbuka akan hal informasi mengenai perusahaan, dan menerima masukan dari karyawan guna memperbaiki lingkungan eksternal agar berdampak baik bagi perusahaan dan hal ini dapat dilihat dari disediakannya kotak kritik dan saran serta membuat website bagi siapa saja yang ingin mengetahui informasi mendalam seputar PT Sari Ater \& Resort Subang.

\section{Kesimpulan}

Berdasarkan hasil penelitian yang peneliti lakukan mengenai budaya organisasi di PT Sari Ater \& Resort Subang Subang Kepuasan kerja karyawan, dengan hasil analisa data yang sudah di bahas maka dapat di simpulkan sebagai berikut : Budaya Organisasi di PT Sari Ater \& Resort Subang dengan beberapa indikator yang dilaksanakan oleh perusahaan adalah Member Identity (Identitas Anggota), Member Identity (Identitas Anggota), Group Emphasis (Penekanan Kelompok), People Focus (Fokus), Unit Intergration (Unit Integrasi), Control (Pengawasan), Risk Tolerance (Toleransi Resiko), Reward Criteria (Kriteria Penghargaan), Conflict Tolerance (Toleransi Konflik), Means-ends Orientation (Cara Berorientasi), Open-sistem Focus (Sistem yang Terbuka).

1. Dilihat dari identitas anggota bahwasanya pendidikan penting dalam pekerjaan ini untuk memudahkan karyawan memahami sesuatu yang baru yang diterapkan dalam perusahaan, terutama lulusan akademik kepariwisataan dan perhlotelan yang paling dibutuhkan.

2. PT Sari Ater \& Resort Subang mengarahkan kepada karyawannya untuk lebih mementingkan penekanan dalam kelompok pada saat melaksanakan pekerjaannya, hal ini akan lebih memudahkan karyawan untuk menyelesaikan pekerjaannya. 
3. Pihak manajemen selalu hati-hati dan mempertimbangkan setiap keputusankeputusan maupun aturan untuk kepentingan karyawan maupun perusahaan

4. Setiap Unit yang ada di dalam perusahaan diarahkan untuk saling membantu dan bekerjasama demi tercapainya tujuan perusahaan.

5. Semua elemen dalam perusahaan sudah baik, hanya saja dalam konteks pengawasan belum maksimal, karena pengawasan tidak langsung oleh bagian SDM melainkan oleh kepala di setiap unitnya.

6. Adanya kotak kritik dan saran bagi karyawan memudahakan agar apabila seorang karyawan memiliki keluhan terhadap pihak manajemen dapat tercurahkan.

7. Di samping itu perusahaan memberikan upah/gaji kepada karyawan sesuai dengan aturan yang berlaku yang seharusnya karyawan dapatkan dan selain dari gaji/upah tersebut karyawan juga mendapatkan bonus seperti THR dsn bonus lainnya, bonus yang di dapatkan sesuai dengan kinerja karyawan. Namun dalam situasi covid 19 banyak karyawan yang mengeluh.

8. Adanya konflik dalam setiap perusahaan dapat menghambat proses pencapaian tujuan, maka dari itu perusahaan memberikan keleluasaan bagi karyawan apabila mendapat keluhan dan pekerjaan kurang nyaman segera lapor dan terbuka akan hal tersebut terhadap kepala unit atau pihak manajemen.

9. Cara berorientasi karyawan dalam menjalankan tugasnya sudah dikatakan baik, hal ini dilihat dari keakraban antar karyawan pada saat menjalani aktifitas sehari-hari dan adanya komunikasi antara karyawan yang satu dengan karyawan lainnya.

10. PT Sari Ater \& Resort Subang memiliki sistem yang terbuka terhadap karyawan maupun masyarakat, sebagai contoh PT Sari Ater \& Resort Subang membuka website khusus bagi masyarakat yang ingi mengetahui informasiinformasi yang dibutuhkan seputar PT Sari Ater Hotel \& Resort Subang.

\section{Referensi}

Amsyah, Zulkifli. 2003. Manajemen Sistem Informasi. Jakarta: PT Gramedia Pustaka Utama.

Gibson, James L. et al. (1996). Organisasi: Perilaku, Struktur, Proses. Ninuk Adriani. Jakarta: Binarupa Aksara.

Hidayat. 1986. Teori Efektifitas Dalam Kinerja Karyawan. Gajah Mada University Press. Yogyakarta.

Indrawijaya, I.Adam, 2000, Perilaku organisasi, Cetakan Keenam, Sinar Biru Algensindo, Bandung

Mahsun, mohammad. 2006. Pengukuran Kinerja sektor Pelayanan Publik. Yogyakarta: BPFE.

Monier. 2008. Manajemen Pelayanan Umum di Indonesia. Jakarta: PT. Bumi Aksara. 
Moleong, Lexzy J, Metodologi Penelitian Kwalitatif. Bandung: PT Remaja Rosda Karya, 2007.

Moleong , 2005. Metodologi Kualitatif Edisi Revisi. Bandung: PT Remaja Rosdakarya

Miles, M.B. and Huberman, M.A. 1984. Qualitative Data Analysis. London:Sage Publication.

Pasolong, Harbani. 2007. Teori Administrasi Publik. CV. Alfabeta. Makassar.

P. Robins, Stephen, 1990, Teori Organisasi, Struktur, Desain dan Aplikasi, Arcan, Jakarta.

Siagian, P.Sondang, 1995, Teory Motivasi dan aplikasinya, Cetakan kedua,Rineka Cipta,Jakarta.

Sinambella Lijan poltak dkk. 2008. Reformasi Pelayanan Publik. Jakarta:Bumi Aksara. 